\title{
INVASIVE PLANTS AND THE GREEN INDUSTRY
}

\section{By Robin A. Harrington', Ronald Kujawski², and H. Dennis P. Ryan ${ }^{3}$}

\begin{abstract}
There are many motivations for introducing plant species to areas outside their native range. Non-native plants can provide food, medicine, shelter, and ecosystem services, as well as aesthetic value. However, some species, such as Norway maple (Acer platanoides), Japanese barberry (Berberis thunbergii), and Oriental bittersweet (Celastrus orbiculatus), have escaped from cultivation, with severe ecological and economic consequences. The approval of a National Invasive Species Management Plan in June 2001 has major implications for future plant introductions and has generated concern in the green industry. There is general agreement among plant professionals regarding (1) a need for education of industry people and client groups on the issue of invasive species, (2) minimizing economic disruption to the nursery industry, and (3) requirements for objective data to support listing of species as invasive. Nursery and landscape associations in several states have already taken steps toward listing invasive species in cooperation with conservation organizations. This proactive approach ensures industry representation and input in developing policy and, when coupled with intense and ongoing educational programs for industry people and their clients, could dramatically reduce the introduction and spread of invasive species.

Key Words. Invasive plants; Norway maple; Japanese barberry; Oriental bittersweet; Acer platanoides; Berberis thunbergii; Celastrus orbiculatus.
\end{abstract}

For centuries, there have been many motivations for human dispersal of plant species around the globe. We have long recognized the importance of non-native plants in providing food, medicine, shelter, and ecosystem services, as well as cultural enjoyment (Ewel et al. 1999; Mack 2001). Introducing new plants has been a common cultural phenomenon since the beginning of time. In North America, the Spanish were the first Europeans to introduce a new tree to the Americas, the peach. The northern Europeans brought with them other food trees such as apple, pear, and cherry. It wasn't until the1860s that serious effort went into collecting new plants for America. Some of the famous collectors of this period were Dr. George Hall, who worked for 15 years in China; Dr. Charles Sargent of the Arnold Arboretum; and Professor William Clark of the Massachusetts Agricultural College, who collected plants while working with the Japanese to establish an agricultural college in Sapporo during 1876. Until recently, state and federal wildlife offices were recommending the planting of introduced species, such as autumn olive (Elaegnus umbellata) and multiflora rose (Rosa multiflora), for wildlife food and cover.

Despite the many benefits provided by introduced species, there has been growing concern recently among land managers regarding the negative impacts when introduced species escape cultivation and become invasive in local habitats. Invasive plant species pose a major threat to biodiversity, habitat quality, and ecosystem function. Invasive plants can also have devastating economic impacts, through loss of revenue (reduced agricultural and silvicultural production in the presence of invasive species) and the high costs associated with control programs. The magnitude of these impacts resulted in Executive Order 13112, issued by President Clinton on February 3, 1999, directing all federal agencies to prevent and control introductions of invasive species. On January 18, 2001, the National Invasive Species Council approved a National Invasive Species Management Plan (www.invasivespecies.gov/council/nmp.shtml), which has major implications for the future introduction of plant species that will in turn impact the horticulture industry.

Our objectives are to (1) present an overview of the concerns that have led to the National Invasive Species Management Plan, (2) present examples of the impacts of three important nursery species when they invade natural and managed areas, and (3) propose strategies to address the concerns of the green industry regarding constraints on future plant introductions and distribution.

\section{WHAT IS AN INVASIVE?}

In any discussion of the negative impacts of invasive plant species, it is important to put the invasive species issue into context. First of all, not all introduced species become invasive. In fact, only a small proportion do. Williamson and Fitter (1996) proposed the "Tens Rule" based on statistical analysis of a number of British animals and plants. The rule states that, on average, one in ten species introduced (either intentionally or accidentally) will escape from cultivation. Only one in ten of these escaped species will become naturalized and form selfsustaining populations. In turn, only one in ten of these naturalized species will likely become invasive. However, because of the vast number of introductions over the years, even the relatively small percentage of the total that become invasive has resulted in a great number of invasive plant species.

One of the major exceptions to the Tens Rule, where the chance of moving from one stage in the invasion process to the next is much greater than $10 \%$, includes plants intro- 
duced intentionally for cultivation. This fact is not surprising because these species are selected to do well in the region where they are introduced. Also, characteristics that make species desirable as street trees or ornamental plantings also increase the likelihood that they will become invasive. Urban and suburban sites typically require plants that will be able to survive in harsh conditions. In many cases, the plants are put into a poor soil with low oxygen conditions. They are exposed to rapid changes in air temperature, and the light conditions can be poor. A tree that can live in these conditions is a survivor and can live just about anywhere.

However, the success of an invasion is affected not only by the characteristics of the invader but also by the characteristics of the site being invaded. There has been growing interest in developing the ability to predict which sites are most susceptible to invasion. There is general agreement among managers and scientists that invasion is facilitated by disturbance. Disturbance increases plant invasions by providing suitable microsites for germination and seedling establishment and by increasing light and nutrient availability that enhance seedling survival and growth (Orians 1986; Hobbs and Huenneke 1992). Invasive species are better able to take advantage of high resource availability than many native species. For example, germination and seedling survival of two invasive woody species, paperbark (Melaleuca quinquinerva) and Brazilian pepper (Schinus teribinthifolius), were greater in disturbed communities than in intact native communities (Ewel 1986). Opening up of forest canopies through management activities or natural disturbance increases light availability and often favors growth and survival of invasive species (Horvitz et al. 1998; Knapp 1998). Although natural disturbance has sometimes been implicated in the establishment of invasive species in natural areas (Horvitz et al. 1998), our increasing fragmentation of the landscape, especially at the suburban-rural interface, is responsible for the establishment and spread of a great number of invasive species.

Recent observations of succesfful invasions in intact forest ecosystems indicate that although disturbance facilitates invasion, it is not a prerequisite. Certain shade-tolerant species have been able to establish in forest understories with dire consequences for silvicultural and natural area management. We will present three examples across a range of growth forms: a tree, a shrub, and a vine. We will describe the characteristics that make these invasive species desirable as street trees and ornamental plantings, which of these characteristics increase their invasiveness, and the consequences of their invasion in forest habitats.

\section{Norway Maple}

Norway maple (Acer platanoides) is a commonly planted street tree in the United States because of its ability to tolerate stressful urban environments, combined with its ease of propagation and a variety of desirable cultivars (Nowak and Rowntree 1990). From this widespread planting, Norway maple has become naturalized and has readily spread into urban woodlands (Bertin et al. 2001) and other intact forests (Webb and Kaunzinger 1993) where it reduces understory biodiversity (Wyckoff and Webb 1996). Norway maple has been overused as a street tree because it was readily available when Dutch elm disease eliminated most American elms (Ulmus americana) as our principal city tree. Norway maple was and is inexpensive and, when planted in tough urban conditions it did well, resulting in attractive, treelined streets.

\section{Japanese Barberry}

Japanese barberry (Berberis thunbergii) is a thorny, perennial shrub native to central and southern Japan (Ohwi 1965). It was first planted in North America in the late 1800s. By the 1920s, the species was naturalized in New England and, by the middle of the century, it was considered a pest (Silander and Klepeis 1999). The primary reason it was planted, and continues to be planted, is its attractive foliage and berries (Figure 1). In addition, it is often planted as a hedge because its thorny branches and bushy habit make an effective barrier (Ehrenfeld 1997).

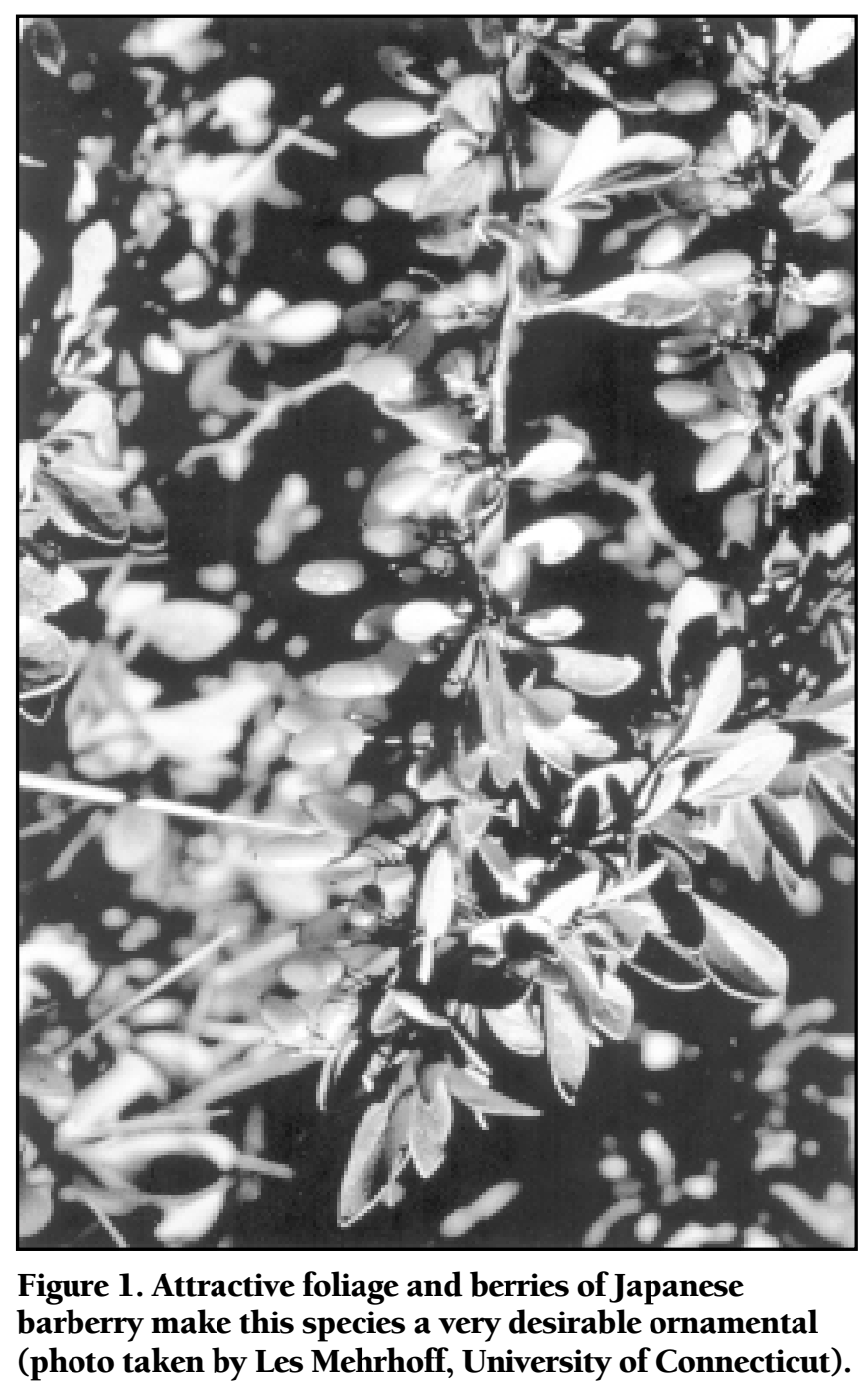


Several characteristics of barberry physiology and anatomy facilitate the spread of the species and cause it to form dense thickets in some areas. Barberry can form dense stands because of the high initiation rate of stems grown from existing root collars, clonal spread by stems that form adventitious roots, and high rates of seedling recruitment (Ehrenfeld 1999). Barberry foliage is unpalatable to deer, so there is little mortality due to browsing (Ehrenfeld 1997). The berries are eaten and the seeds spread by a variety of animal species, including white-tail deer, turkeys, and grouse (Ehrenfeld 1997). Barberry can survive and grow in a broad range of light and moisture conditions. However, barberry is of particular concern because it is able to invade intact forest understory habitats where it forms impenetrable thickets and prevents natural forest regeneration (Figure 2). Barberry is extremely shade tolerant; it can survive in as little as $1 \%$ full sun and can produce berries in conditions of only 4\% full sun (Silander and Klepeis 1999). However, this species also responds readily to increases in light and nitrogen availability (Cassidy 2002).

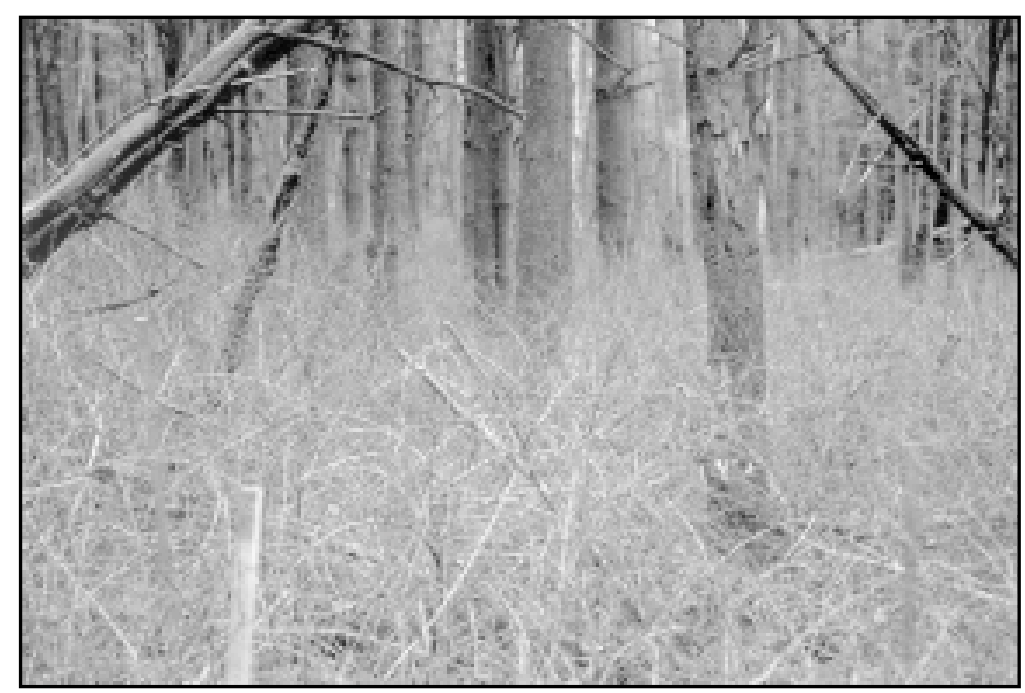

Figure 2. The combination of multiple arching stems produced from each root collar and the ability of these stems to form adventitious roots when they lean over and touch the soil allows Japanese barberry to form impenetrable thickets (photo taken by Robin Harrington).

\section{Oriental Bittersweet}

Oriental bittersweet (Celastrus orbiculatus) is a deciduous, woody vine that was introduced as an ornamental from eastern Asia in 1860. It has become naturalized in the northeastern United States and is now present in every county in Massachusetts (Sorrie and Somers 1999). Bittersweet produces abundant fruits that are readily dispersed by birds. The colorful fruits also make bittersweet a very desirable ornamental, which may increase the likelihood that it will continue to be planted and spread across the landscape. Oriental bittersweet is considered a pest by many land managers because of its ability to readily overtop native trees and shrubs along roadsides, in clearings, and in forest gaps (Dreyer et al. 1987; McNab and Meeker 1987) (Figure 3). In a recent study, this vine species grew an average of $4.5 \mathrm{~m}$ in length over 12 weeks in partial shade, with certain individuals growing up to $9 \mathrm{~m}$ over the same interval (Ellsworth 2002). Bittersweet seeds are able to germinate in a variety of light conditions, including partial and dense shade (Patterson 1974). The species is also very adaptable; in one experiment, shade-grown plants altered their photosynthetic light response to nearly that of sun-grown plants in 8 days (Patterson 1975). This ability could explain its rapid domination of gaps following disturbances such as windthrow, timber harvesting, and road construction. Rapid growth over stumps, saplings, and adult trees leads to silvicultural problems by suppressing natural regeneration and planted stock through shading, girdling, and stem deformity, and the added weight increases the possibility of ice damage (McNab and Meeker 1987). In addition to effects on individual tree growth and survival, it is possible that growing from tree to tree increases the likelihood of multiple trees falling together as a result of logging or windthrow (Putz 1991).

\section{CONCERN OF GREEN INDUSTRY}

The green industry may feel unfairly targeted while trying to satisfy the public demand for non-native species. However, $85 \%$ of woody invasive species in North America were introduced by the landscape industry (Reichard and Hamilton 1997); therefore, dialog between landscape industry and natural area managers needs to be established.

Some state nursery and landscape associations are actively addressing the issue. For example, in Massachusetts, representatives of the Massachusetts Nursery and Landscape Association (MNLA) sit on the Massachusetts Invasive Plant Evaluation Committee, which is currently evaluating criteria for determining invasive plants and developing a list of invasives based on that criteria. The executive director of MNLA co-chairs that committee.

To stimulate discussion among its members, the Virginia Nursery and Landscape Association (VNLA) through its newsletter (Bruce 2001) has published a list of the 11 plants that the Virginia Native Plant Society has identified as most troublesome (Table 1). The intended outcome of publishing this list is to develop an agreement by VNLA that would remove these plants from production and commercial trade.

On the national level, the American Nursery and Landscape Association (ANLA) has developed a "Voluntary Code of Conduct for Nursery Professionals" to guide the 


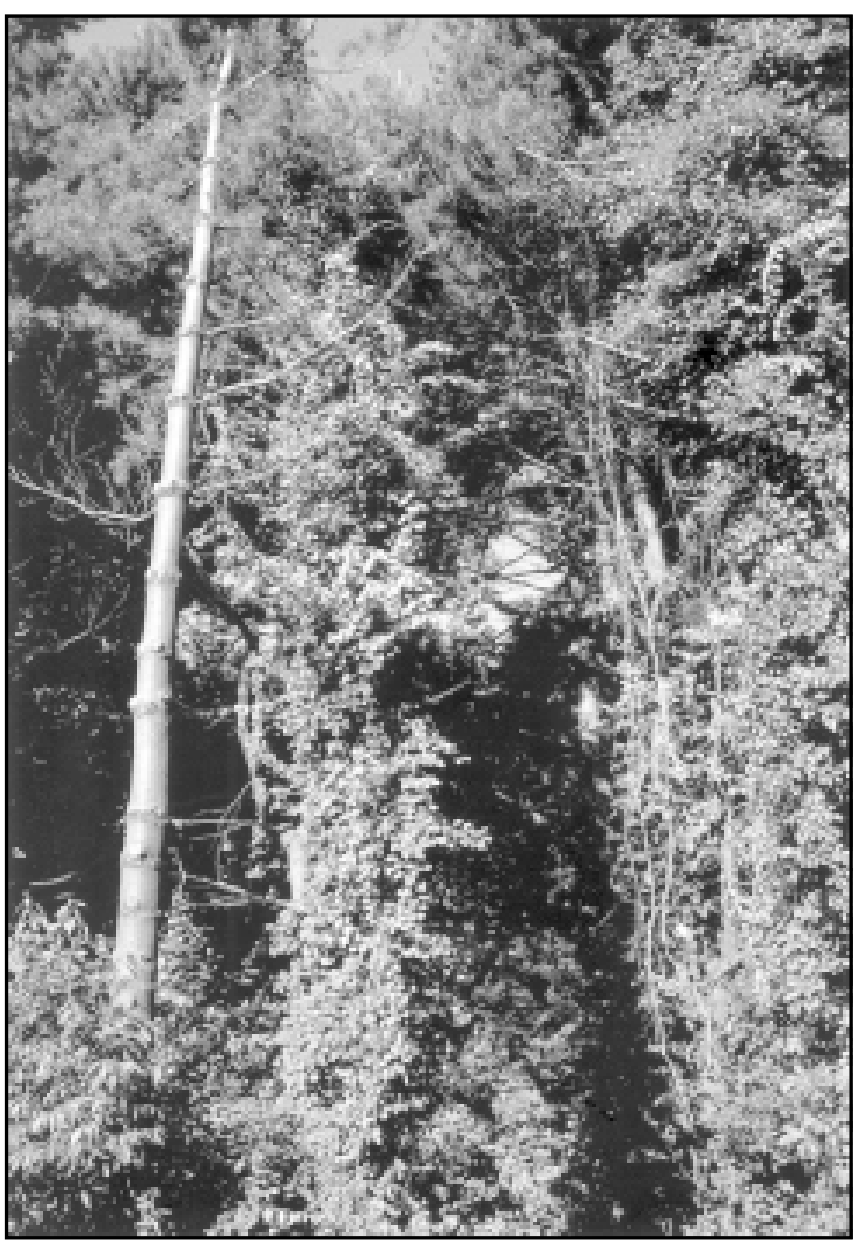

Figure 3. Oriental bittersweet can readily climb and overtop trees along roadsides (photo taken by Robin Harrington).

\section{Table 1. Virginia Native Plant Society list of invasive plants carried by the Virginia nursery industry (Bruce 2001).}

\begin{tabular}{ll}
\hline Tree-of-heaven & Ailanthus altissima \\
Akebia, chocolate vine & Akebia quinata \\
Porcelain berry & Ampelopsis brevipedunculata \\
Oriental bittersweet & Celastrus orbiculatus \\
Autumn olive & Elaeagnus umbellata \\
Weeping love grass & Eragrostis curvula \\
Silver lace, fleece vine & Polygonum aubertii \\
Kudzu & Pueraria montana \\
European eater-milfoil & Myriophyllum spicata \\
Hydrilla & Hydrilla verticillata \\
Parrot's feather & Myriophyllum aquaticum
\end{tabular}

actions of plant professionals in dealing with invasive plants. Among the provisions in the code (http://www.mobot.org/ iss/nurserycode2.htm) is the following: "Where agreement has been reached among nursery associations and govern- ment, academia, ecology, and conservation organizations on specific invasive species, phase out existing stocks of those species in regions where they are considered a threat."

American Nurseryman, a trade magazine, conducted a roundtable discussion (American Nurseryman 1999) with nine plant professionals to gather their views on the invasive plant issue. Several common themes were expressed by the participants. Themes included a need for education of industry people and client groups on the issue of invasives; minimizing economic disruption to the nursery industry; and requirement for objective data to support listing of species as invasive.

The primary concerns expressed by the green industry center on a perceived broad-brush approach to the invasive issue. There is fear that national mandates prohibiting the sale or use of certain plant species in all regions of the country would be unnecessarily restrictive in some cases. Due to regional climate and environmental differences, species that may be invasive in one region would not be invasive in others, yet federal regulations would prohibit their use anywhere. There is a preference for regional solutions or mandates to coping with some identified invasive species.

Another concern is the exclusion of industry representation on and input in bodies that are involved in developing policy. The industry feels strongly that they must be included in any decision making that affects their business. The preference of the industry (and many nonindustry groups, for that matter) is that voluntary standards be established for the industry, coupled with intense and ongoing educational programs for industry people and their clients.

The emphasis on a "natives only" alternative to invasive plants by some is also a concern to the industry. While green-industry people grow, sell, and plant native species, the bulk of plant materials in their inventory are made up of non-native species, the vast majority of which are not identified in any way as being invasive. Industry people would prefer that the invasive plant issue and native plant issue be kept separate.

\section{COMMON GROUND}

In the past, invasive species have been used extensively throughout urban-to-rural gradients across the landscape. However, based on current knowledge, it's clear that we need to limit the use of identified invasive plants. Some invasive plant species should be banned completely because they are so destructive and costly to manage. Some other plants should be limited to urban areas. Some groups want to limit the green industry to using only native plants and, although the authors support the use of native species in general, we feel this practice could actually increase the management of plant problems in some cases. As an example, we have available American sycamore (Platanus occidentalis) and London planetree (Platanus acerifolia) that 
can be specified as park or street trees. They are similar in appearance and will grow as street trees. While American sycamore is frequently infected with anthracnose, London planetree is not seriously infected with the disease and, importantly, is not invasive.

Along with the need to understand and mitigate the impacts of invasive plant species already in the landscape, we need to stop the introduction of species known to be invasive and to prevent the introduction of new species that may have the potential to be invasive. Several methods for predicting which species could become invasive have been proposed (Mack 1996). One approach relies on identifying key ecological and life history characteristics common to many invasive plant species (Newsome and Noble 1986; Rejmánek and Richardson 1996), but it is also important to look at current geographic distributions of species. Plants with a wide geographic native range are more likely to become invasive when they are introduced elsewhere because of their ability to tolerate a wide range of conditions (Goodwin et al. 1999). Also, species that have proven to be invasive elsewhere are more likely to become invasive following new introductions (Reichard and Hamilton 1997). The ideal approach would result in rejection of all potentially invasive species while minimizing the rejection of noninvasive species. The most promising approaches incorporate the biological and ecological characteristics of the species, biogeographical information, and status of the species as a weed elsewhere (Reichard and Hamilton 1997; Pheloung et al. 1999).

\section{CONCLUSIONS}

Education will be the key to reducing the problems associated with invasive plants. The green industry and environmental groups need to finish and publish their lists of problem plants. While state-by-state lists could be produced, regional lists would be better. Landscape architects, tree wardens, and other professionals involved with the writing of planting specifications need to adopt the new plant guidelines. To accomplish this goal, we will have to educate the general public that some of their favorite plants will no longer be available. We will need to replace some of these popular plants with sterile hybrids or other plant species.

Lastly, the green industry needs to take a proactive role by working with environmental groups in identifying the problems. By working to reduce an increasingly serious situation, the green industry will assist in ensuring that our natural areas remain natural.

\section{LITERATURE CITED}

American Nurseryman. 1999. Invasives roundtable. Am. Nurseryman 190(2):54-77.

Bruce, J. 2001. News_Invasive plants? Let us know! Va. Nursery Landscape Assoc. Newsl. 71(1):17.
Bertin, R.I., T. Cantwell, and B. Berstene. 2001. Introduced Tree Species in Urban Woodlands in Worcester, Massachusetts. Poster given at the 86th Annual Meeting of the Ecological Society of America, 5-9 August 2001, Madison, WI,

Cassidy, T.M. 2002. Effects of soil acidity and resource availability on the growth of Japanese barberry (Berberis thunbergii). M.S. Thesis, Department of Natural Resources Conservation, University of Massachusetts, Amherst, MA.

Dreyer, G.D., L.M. Baird, and C. Fickler. 1987. Celastrus scandens and Celastrus orbiculatus: Comparisons of reproductive potential between a native and an introduced woody vine. Bull. Torrey Bot. Club 114:260-264.

Ehrenfeld, J.G. 1997. Invasion of deciduous forest preserves in the New York metropolitan region by Japanese barberry (Berberis thunbergii DC.). J. Torrey Bot. Soc. 124:210-215.

_ 1999. Structure and dynamics of populations of Japanese barberry (Berberis thunbergii DC.) in deciduous forests of New Jersey. Biol. Invas. 1:203-213.

Ellsworth, J.W. 2002. Controls on the establishment and early growth of Oriental bittersweet (Celastrus orbiculata Thunb.). M.S. Thesis, Department of Natural Resources Conservation, University of Massachusetts, Amherst, MA.

Ewel, J.J. 1986. Invasibility: Lessons from South Florida, pp 214-230. In Mooney, H.A., and J.A. Drake (Eds.). Ecology of Biological Invasions of North America and Hawaii. Springer-Verlag, New York, NY.

Ewel, J.J., D.J. O’Dowd, J. Bergelson, C.C. Daehler, C.M. D'Antonio, L.D. Gomez, D.R. Gordon, R.J. Hobbs, A. Holt, K.R. Hopper, C.E. Hughes, M. LaHart, R.R.B. Leakey, W.G. Lee, L.L. Loope, D.H. Lorence, S.M. Louda, A.E. Lugo, P.B. McEvoy, D.M. Richardson, and P.M. Vitousek. 1999. Deliberate introductions of species: Research needs. BioScience 49:619-630.

Goodwin, B.J., A.J. McAllister, and L. Fahrig. 1999. Predicting invasiveness of plant species based on biological information. Conserv. Biol. 13:422-426.

Hobbs, R.J., and L.F. Huenneke. 1992. Disturbance, diversity, and invasion: Implications for conservation. Conserv. Biol. 6:324-337.

Horvitz, C.C., J.B. Pascarella, S. McMann, A. Freedman, and R.H. Hofstetter. 1998. Functional roles of invasive nonindigenous plants in hurricane-affected subtropical hardwood forests. Ecol. Appl. 8:947-974.

Knapp, L.B. 1998. Growth of Ailanthus altissima in Old Growth Forest Gaps. M.S. Thesis, Bard College, Annandale-on-Hudson, NY. 74 pp.

Mack, R.N. 1996. Predicting the identity and fate of plant invaders: Emergent and emerging approaches. Biol. Conserv. 78:107-121.

-2001. Motivations and consequences of the human dispersal of plants, pp 23-34. In McNeely, J.A. (Ed.). The Great Reshuffling: Human Dimensions of Invasive Alien Species. ICUN, Gland, Switzerland, and Cambridge, UK. 
McNab, W.H., and M. Meeker. 1987. Oriental bittersweet: A growing threat to hardwood silviculture in the Appalachians. North. J. Appl. For. 4:177-180.

Newsome, A.E., and I.R. Noble. 1986. Ecological and physiological characteristics of invading species, pp 1-20. In Grooves, R.H., and J.J. Burdon (Eds.). Ecology of Biological Invasions. Australian Academy of Science, Sydney, Australia, and Cambridge University Press, New York, NY.

Nowak, D.J., and R.A. Rowntree. 1990. History and range of Norway maple. J. Arboric. 16:291-296.

Ohwi, J. 1965. Flora of Japan. Smithsonian Institution, Washington, DC.

Orians, G.H. 1986. Site characteristics favoring invasions, pp 133-148. In Mooney, H.A., and J.A. Drake (Eds.). Ecology of Biological Invasions of North America and Hawaii. Springer-Verlag, New York, NY.

Patterson, D.T. 1974. The Ecology of Oriental Bittersweet, Celastrus orbiculatus, a Weedy Introduced Ornamental Vine. Ph.D. Dissertation, Duke University, Durham, NC.

_ 1975. Photosynthetic acclimation to irradiance in Celastrus orbiculatus Thunb. Photosynthetica 9:140-144.

Pheloung, P.C., P.A. Williams, and S.R. Halloy. 1999. A weed risk assessment model for use as a biosecurity tool evaluating plant introductions. J. Environ. Manage. 57:239-251.

Putz, F.E. 1991. Silvicultural effects of lianas, pp 493-501. In Putz, F.E., and H.A. Mooney (Eds.). The Biology of Vines. Cambridge University Press, Cambridge, UK.

Reichard, S.H., and C.W. Hamilton. 1997. Predicting invasions of woody plants introduced into North America. Conserv. Biol. 11:193-203.

Rejmánek, M., and D.M. Richardson. 1996. What attributes make some plant species more invasive? Ecology 77:1655-1661.

Silander, J.A. Jr., and D.M. Klepeis. 1999. The invasion ecology of Japanese barberry (Berberis thunbergii) in the New England landscape. Biol. Invas. 1:189-201.

Sorrie, B.A., and P. Somers. 1999. The Vascular Plants of Massachusetts: A County Checklist. Massachusetts Division of Fisheries and Wildlife Natural Heritage \& Endangered Species Program, Westborough, MA.

Webb, S.A., and C.K. Kaunzinger. 1993. Biological invasion of the Drew University (New Jersey) Forest Preserve by Norway maple (Acer platanoides L.). Bull. Torrey Bot. Club 120:343-349.

Wyckoff, P.H., and S.L. Webb. 1996. Understory influence of the invasive Norway maple (Acer platanoides). Bull. Torrey Bot. Club 123:197-205.

Williamson, M., and A. Fitter. 1996. The varying success of invaders. Ecology 77:1661-1666.

\author{
1,3* Department of Natural Resources Conservation \\ University of Massachusetts \\ Amherst, MA 01003, U.S. \\ ${ }^{2}$ Horticultural Consultant \\ Great Barrington, MA 01230, U.S.
}

"Corresponding author: Robin A. Harrington.

Résumé. Il existe plusieurs raisons pour introduire des espèces de végétaux hors de leur aire naturelle. Les plantes non indigènes peuvent produire de la nourriture et des médicaments, fournir un abris, ou encore rendre des services écologiques ou avoir une valeur esthétique. Par contre, certaines espèces, comme l'Acer platanoides, le Berberis thunbergii et le Celastrus orbiculatus se sont échappées de culture avec des conséquences écologiques et économiques sévères. L'adoption du Plan national de gestion des espèces envahissantes en juin 2001 a eu des implications majeures sur l'introduction futures de plantes et a généré des inquiétudes au sein de l'industrie verte. Il y a entente générale entre les professionnels du monde végétal quant 1) à un besoin d'éducation des gens de l'industrie et des groupes de clients à propos des conséquences des plantes envahissantes, 2) à une minimisation des perturbations économiques au sein de l'industrie des pépinières, et 3) au besoin de données objectives pour supporter l'établissement d'une liste des espèces envahissantes. Les associations de pépiniéristes et de paysagistes de plusieurs états ont déjà pris des initiatives pour lister les espèces envahissantes en coopération avec les organismes de conservation. Cette approche proactive assure à l'industrie sa représentation dans le développement d'une politique et, lorsque cela est couplé avec des programmes d'éducation intensifs et constants envers les gens de l'industrie et leurs clients, il peut alors y avoir une diminution dramatique de l'introduction et de la dissémination des espèces envahissantes.

Zusammenfassung. Es gibt viele Gründe und Anreize, Pflanzen außerhalb ihres natürlichen Verbreitungsgebietes anzusiedeln. Nicht endemische Pflanzen können neben ästhetischen Werten auch Nahrung, Medizin, Schutz und Öko-Nische bieten. Dennoch sind einige Arten wie der Spitzahorn, Japanese Barberry und Oriental Bittersweet aus ihrer Kultivierung entflohen und haben schwere ökologische und ökonomische Konsequenzen nach sich gezogen. Die Anstrengungen eines nationalen Konzepts zum Management invasiver Pflanzen im Juni 2001 hatte bedeutende Auswirkungen auf künftige Pflanzenimporte und erzeugte große Betroffenheit in der "Grünen Branche”. 
Es gibt ein generelles Einverständnis unter der Professionellen 1. bezüglich eines Bildungsbedarfs in der Industrie und der an Importen interessierten Klientel, 2. im Minimieren einer ökonomischen Unterbrechung in der produzierenden Baumschulindustrie und 3. in den Anforderungen für objektive Daten und Fakten, um die betroffenen Pflanzen überhaupt zu klassifizieren und zu listen. Baumschul- und Landschaftsbauverbände in verschiedenen Bundesstaaten haben bereits Schritte unternommen, um die Listung invasiver Arten in Kooperation mit den landschaftserhaltenden Organisationen zu erreichen. Dieser proaktive Ansatz sichert Industriepräsentation und einen Input in der Entwicklungspolitik und könnte, wenn er verbunden wird mit intensiven und fortlaufenden Ausbildungsprogrammen für Industriebeschäftigte und ihre Klientel die Einführung und Verbreitung invasiver Pflanzen drastisch reduzieren.

Resumen. Existen muchas motivaciones para la introducción de especies de plantas a áreas fuera de su rango nativo. Las plantas no-nativas pueden proporcionar alimento, medicina, abrigo, y servicios al ecosistema, como también valor estético. Sin embargo, algunas especies, tales como el maple Norway y el cerezo Japonés, han escapado del cultivo, con severas consecuencias ecológicas y económicas. El Plan Nacional de Manejo de Especies Invasoras aprobado en Junio de 2001 tiene implicaciones para la introducción de plantas en el futuro y ha generado preocupación en la industria verde. Existe un acuerdo general entre los profesionales de las plantas en cuanto a (i) una necesidad de educación a la gente de la industria y grupos de clientes en el tema de las especies invasoras, (ii) minimizar el impacto económico en la industria de los viveros, y (iii) requerimiento de datos objetivos de soporte de listas de especies invasoras. Los viveros y las asociaciones paisajísticas en varios estados han tomado iniciativas en el sentido de elaborar las listas en cooperación con organización de conservación. Esta aproximación asegura representación a la industria en el desarrollo de políticas, y cuando se trabaja en programas educativos para la gente de la industria y los clientes, se podría reducir dramáticamente la introducción y dispersión de especies de plantas invasoras. 